\title{
An Analysis of the Vegetables Supply Chain in Swaziland
}

\author{
Bongiwe G. Xaba ${ }^{1} \&$ Micah B. Masuku ${ }^{2}$ \\ ${ }^{1}$ P.O. Box C565, Manzini, M200, Swaziland \\ ${ }^{2}$ Department of Agricultural Economics and Management, P. O. Luyengo, Luyengo. M205. University of \\ Swaziland, Swaziland \\ Correspondence: Micah B. Masuku, Department of Agricultural Economics and Management, P. O. Luyengo, \\ Luyengo. M205. University of Swaziland, Swaziland. Tel: 268-7602-6557. E-mail: mbmasuku@uniswa.sz
}

Received: August 13, 2012 Accepted: September 28, 2012 Online Published: November 6, 2012

doi:10.5539/sar.v2n2p1 URL: http://dx.doi.org/10.5539/sar.v2n2p1

\begin{abstract}
The total consumption of fresh vegetables in Swaziland is estimated around 40,000 tonnes per year and this translate into $40 \mathrm{~kg}$ per capita consumption per year. Individuals who are not economically challenged consume above the annual per capita of $40 \mathrm{~kg}$ in contrast to a poor individuals living in rural areas, who consume less than the per capita vegetables. The study sought to describe the performance of vegetable vegetables supply chain in Swaziland. A descriptive research design was used in the study and data were collected using personal interviews from 100 randomly selected vegetable farmers. Data were analysed using market margins and marketing channel analysis to identify existing marketing channels used by vegetable farmers. The revealed marketing channels that producers used to obtain attractive prices and a higher share of the consumer price. The largest producer's share was obtained through direct sale to consumers. Channels that included restaurants had high total gross margins and low producer's share of the consumer price. The concern for issues on post-harvest and marketing should form an integral part of policy development and research programmes and also the public and private sectors should facilitate contractual arrangements for vegetables farmers. Commercialising vegetable production should not be overemphasised because it encourages farmers to be market oriented as opposed to production oriented. Farmers need to form cooperatives in order to assist in bargaining of prices within the vegetable supply chain.
\end{abstract}

Keywords: vegetable production, vegetable supply chain, marketing channels, market margins and market performance

\section{Introduction}

The agricultural sector is characterised by a dualistic nature consisting of modern and traditional sectors. About $80 \%$ of the Swazi population lives on Swazi Nation Land (SNL). They derive their livelihood from subsistence agricultural production (Thompson, 2011). Vegetable production on SNL is practiced by subsistence farmers and less than 7 percent of all SNL are planted to rain-fed crops, with maize being the most important crop (FAO/WFP, 2002).

Thus, to improve income and provide gainful employment, diversification from grain crops to high-value crops like vegetables has emerged as an important strategy for agricultural growth (Sekhon \& Kaur, 2004). Swaziland promotes the production of different crops in order to avoid glut of the same crop in the market (Sithole \& Grenoble, 2010). Vegetables play an important socio-economic role especially in the rural areas. They create job opportunities on the farm by rotating with cereals thus generating additional incomes that enhance the purchasing power of rural communities. The main vegetables currently grown in Swaziland include cabbage, carrot, onion and tomato, whilst the major fruits are banana, avocadoes and pineapples (NAMBoard, 2009). The production of vegetables is seasonal and farmers, especially on Swazi Nation Land produce maize in summer and vegetables in winter (NAMBoard, 2009).

The increasing demand for fruits and vegetables as a results rising incomes and changing consumption patterns coupled with declining farm incomes due to increase in costs and stagnating food grain productivity has necessitated diversification towards high-value crops in recent times. Apart from income enhancement, high-value crops have a potential to generate additional employment opportunities in farming due to their labour-intensive character.

Swaziland has good physical environment for promoting vegetable production (Sithole \& Grenoble, 2010). The 
climate favours the production of different types of vegetables, while soils are also generally good and water for crop production is adequate (Sithole \& Grenoble, 2010). However, improvements in ensuring water distribution would improve the competitiveness of the horticulture sector.

\subsection{Production and Marketing of Vegetables in Swaziland}

In Swaziland a variety of vegetable crops are grown by smallholder farmers for income and food. They are grown under various production systems, which vary from cultivating a few plants in the back yard for consumption to commercial production for processing or export. Table 1 presents the common vegetables produced in Swaziland between 2005 and 2009. Table 1 shows that 559 vegetable farmers produced cabbages, tomatoes, carrots and onions under a total area of 353.7 hectares.

Table 1. Common vegetables produced in Swaziland in 2005-2009

\begin{tabular}{lllllll}
\hline $\begin{array}{l}\text { Vegetable } \\
\text { Crop }\end{array}$ & Hectares & $\begin{array}{l}\text { Number } \\
\text { farmers }\end{array}$ & $\begin{array}{l}\text { Average } \\
\text { returns/ ha }\end{array}$ & $\begin{array}{l}\text { Cost of Production } \\
(\mathrm{E})\end{array}$ & $\begin{array}{l}\text { Contribution to GDP } \\
(\mathrm{E})\end{array}$ \\
\hline Cabbage & 154.8 & 310 & 83,332 & 18,481 & 64,852 \\
Tomatoes & 72.5 & 145 & 105,000 & 22,602 & 82,398 \\
Carrots & 96.8 & 37 & 105,000 & 15,170 & 89,829 \\
Onions & 30.4 & 61 & 62,500 & 21,097 & 41,402 \\
TOTAL & 353.7 & 559 & 355832 & 77350 & 278481 \\
\hline
\end{tabular}

Source: NAMBoard, 2009.

E, refers to Emalangeni and E1, is equal to US\$ 8.3.

The Government of Swaziland through the National Agricultural Marketing Board (NAMBoard) has over the past 15 years encouraged Swazi farmers to grow baby vegetables as a diversification strategy (Thompson, 2011). Farmers have heeded the advice by government and have embraced the practice of baby vegetable production. There are currently 120 registered baby vegetable farmers in the country and they are mostly situated in the Swazi Nation Land (NAMBoard, 2009).

Marketing plays a significant function in the performance of supply chains. Farmers require relevant and reliable infrastructure, labour, technology and coordinated markets in order to effectively market their agricultural products. Farmers benefit from markets if their participation minimises transaction costs, hence they should focus on production, which they have a comparative advantage (Porter, 1985). Farmers can choose to sell their produce through different market outlets ranging from local markets, restaurants to retailer and wholesalers. The choice of a particular outlet is determined by its location and the ability of the farmer to meet quality, and food safety standards. Improving vegetable marketing in developing countries such as Swaziland is vital because of the fast growing demand due to urbanization, opportunities it offers in generating income for smallholder farmers by exporting high value crops and providing employment opportunities as a result of its labour intensive production (FAO, 1986).

Vegetable farmers can sell their produce through local traditional markets to local consumers and vendors and through cooperatives to retail agents and wholesalers. Local traditional markets, located in most towns, are supplied by local vendors who purchase at the farm gate and deliver to the markets. However, they prefer to purchase from larger, more reliable farmers in South Africa due to the scattered nature of local production and the unreliability of supply at any given time (NAMBoard, 2009).

Makhura, and Mokoena (2003) identified infrastructure, distance to the market, lack of assets (for example lack of own transport) and inadequate market information as the main constraints to marketing. Lack of bargaining power along with various credit bound relationships with the buyers has led to farmers being exploited during the transaction where most of the farmers become price takers. The majority of the farmers in Swaziland are smallholders, hence they are faced with high production and transaction costs. This results to farmers not being able to sustain their livelihood (Hettige \& Senanayake, 1992; Kodithuwakku, 2000). According to Emana and Gebremedhin (2007) factors such as inadequate markets, low prices, a lot of intermediaries and inadequate marketing institutions and interaction among farmers make it impossible for small-scale farmers to take part in formal markets. 


\subsection{Factors influencing the Performance of Supply Chains}

The agribusiness and food chains are changing from a commodity system organised via spot markets towards a vertically coordinated food system. This leads to competition between supply chains and networks rather than competition between individual firms (Lambert \& Cooper, 2000).

When compared to vertical coordination in the supply chain, some weaknesses are associated with spot markets. For instance, prices and conditions of delivery are negotiated for every transaction carried out on spot markets. This may result in increased marketing costs for the farmer. Moreover, farm gate sales tend to result in lower revenue for farmers since the prices are relatively low and variable. However, smallholder farmers tend to prefer farm gate sales because they receive immediate payments and do not incur transaction costs such as transportation costs and tax payments (Shiferaw et al., 2006).

Abbott and Markham (1981) defined marketing efficiency in terms of the flow of products and services from the point of production to final consumers at minimal cost. Marketing efficiency is measured by market margins. Before choosing a marketing channel, smallholder farmers consider the costs associated with transportation, profits, level of trust among the available brokers and familiarity with the markets, among other factors (Makhura, and Mokoena (2003). In other instances, farmers sell their produce through channels offering low prices because they either lack market information or have difficulties in accessing markets that are more rewarding. The existing channels can be analysed according to price and services provided. Producers can sell their produce directly to retailers and consumers or sell through intermediaries. Vegetable farmers prefer selling through intermediaries because of stability and confidence in local markets, as well as the likelihood of increasing performance through specialisation in sorting, storing and transportation (Stern \& El-Ansary, 1977).

Among the marketing research techniques, market margins are used to evaluate the performance of the vegetable supply chain. The term marketing margin means the difference in the price consumers pay for a product or service and the revenue producers get for the same product. It also implies the price differences between other links within the supply chain. If market margins are high, it means that producers or consumers are being exploited or intermediaries are obtaining higher profits. It may also be that improvement in services or consumer satisfaction result in increase in market margins. Marketing efficiency can be maximized by using strategies that reduce marketing costs: such as the use of co-operatives; increasing the size of activities; improving the business volume; creating awareness of markets among farmers; recruiting experienced market personnel; and introducing novel methods of marketing using managerial control.

The elimination of intermediaries and controlling markets tend to improve returns to producers, and that marketing through co-operatives would promote competitive market conditions for agricultural products. Currently the main institution responsible for the promotion of vegetable production and marketing in Swaziland is NAMBoard (NAMBoard, 2011). However, farmers complain that NAMBoard is competing with farmers by importing vegetables as well as paying unsatisfactory prices for locally produced vegetables. Firms nolonger compete as individuals, but the entire chain competes with other supply chains (Porter, 1985). Swaziland has been continuously importing vegetables from South Africa. Between 2005 and 2009, about 14,782 metric tonnes of vegetables were important (NAMBoard, 2009). Whilst this figure has been steady, there is no study that has been conducted to investigate the performance of the vegetables supply chain in Swaziland. Therefore, it is important to analyse the vegetable supply chain in order to establish its performance with a view to ascertain its efficiency and competitiveness.

\subsection{Objectives of the Study}

The general objective was to investigate the vegetable supply chain in Swaziland. Specifically, the study sought to; identify existing channels used by vegetable farmers to market their vegetables (cabbage, carrot, onion, tomato, baby corn, and baby marrow), and determine market margins within the vegetable supply chain.

\section{Methodology}

\subsection{Research Design}

A descriptive quantitative design was employed in the study with an aim of describing the performance of vegetable supply chain in Swaziland.

\subsection{Sampling Procedure}

The target population was all farmers engaged in vegetable production in Swaziland. An up-to date list of 433 vegetable farmers was obtained from the Ministry of Agriculture and NAMBoard's extension officers. Thus, frame and selection errors were controlled. The vegetable crops studied included cabbage, carrot, onion, tomato, 
baby corn and baby marrow. These crops were included because they account for a larger percentage of vegetables produced in the country and they were in constant supply in the market (Mhlongo, personal communication, 22 September, 2011). The sampling units were conventional and baby vegetable producers in Swaziland. A two stage sampling technique involving purposive and stratified random sampling was used to draw a sample of 100 farmers.

\subsection{Data Collection}

Data were collected through the use of personal interviews using a structured questionnaire. The questionnaire consisted both open and closed-ended questions. The questionnaires were reviewed by experts in the Department of Agricultural Economics and Management to establish content and face validity. Questionnaires were further pretested using farmers who were not part of the sample.

\subsection{Data Analysis}

Data were analysed using descriptive statistics and multinomial logistic regression. The Statistical Package for Social Sciences (Version 17) was use for the analysis.

\subsection{Analytical Technique}

\subsubsection{Marketing Margins}

According to Ghorbani (2008), marketing margin are important indices in the evaluation of supply chain performance. It is the difference in the price paid by consumers and that received by the producers. Marketing margins are also calculated at different points along the supply chain and then compared with consumer price. Ghorbani (2008) defined it as the difference between price or value and he argued that it is a component of commodity price that the farmer does not get.

Marketing costs and marketing margins are the comparison of prices along the supply chain at the same time. It is calculated in relation to the price paid by the consumer and expressed in percentage (Teka, 2009). Thus, the following equations were used to calculate gross margins.

$$
T G M M=\frac{\text { Csprice }- \text { Pdprice }}{\text { Csprice }} \times 100
$$

Producers' gross margin is the percentage of the price paid by the end consumer that belongs to the farmer.

$$
\begin{gathered}
G M M_{p}=\frac{\text { Csprice }-M G M}{\text { Csprice }} \\
\text { Pdshare }=\frac{\text { Pdprice }}{\text { Rtlprice }}
\end{gathered}
$$

Where: TGMM $=$ Total gross marketing margin

GMMp $=$ Producer's gross marketing margin

MGM = Marketing gross margin

Csprice $=$ Consumer's price

Pdprice $=$ Producer's price

Rtlprice $=$ Retail price

Pdshare $=$ Producer's share

\subsubsection{Marketing Channels}

According to Teka (2009) marketing channel analysis provides knowledge of the movement of goods and services from producer to consumer. Ghorbani (2008) studied the different types of marketing channels in Iran and found that some were simple, while others were complex.

\section{Results and Discussion}

\subsection{Vegetable Marketing Channels and Market Margins}

Marketing channel performance and marketing margins were used in the analysis of supply chain performance. According to Teka (2009), a marketing channel involves a series of intermediaries through which vegetables pass from producers to consumers. Figure 1 presents outlets or routes through, which vegetables move from the 
production site until they reach the final buyer. Four parameters are necessary to measure the efficiency of a channel. These are quantity handled, producer's share, total marketing margin, and rate of return, out of which volume handled, producer's share and marketing margin were considered for all the crops in this study. The rate of return was left out due to lack of relevant data. Figure 1 indicates that conventional vegetables (denoted by black line) flow from producers to either direct to consumers, wholesalers, local markets, retailers, or restaurants. From wholesalers and retailers, they flow to local markets, restaurants and consumers. On the other hand baby vegetables flow from farmers to wholesalers and retailers and from retailers to restaurants and consumers or from wholesalers to export markets.

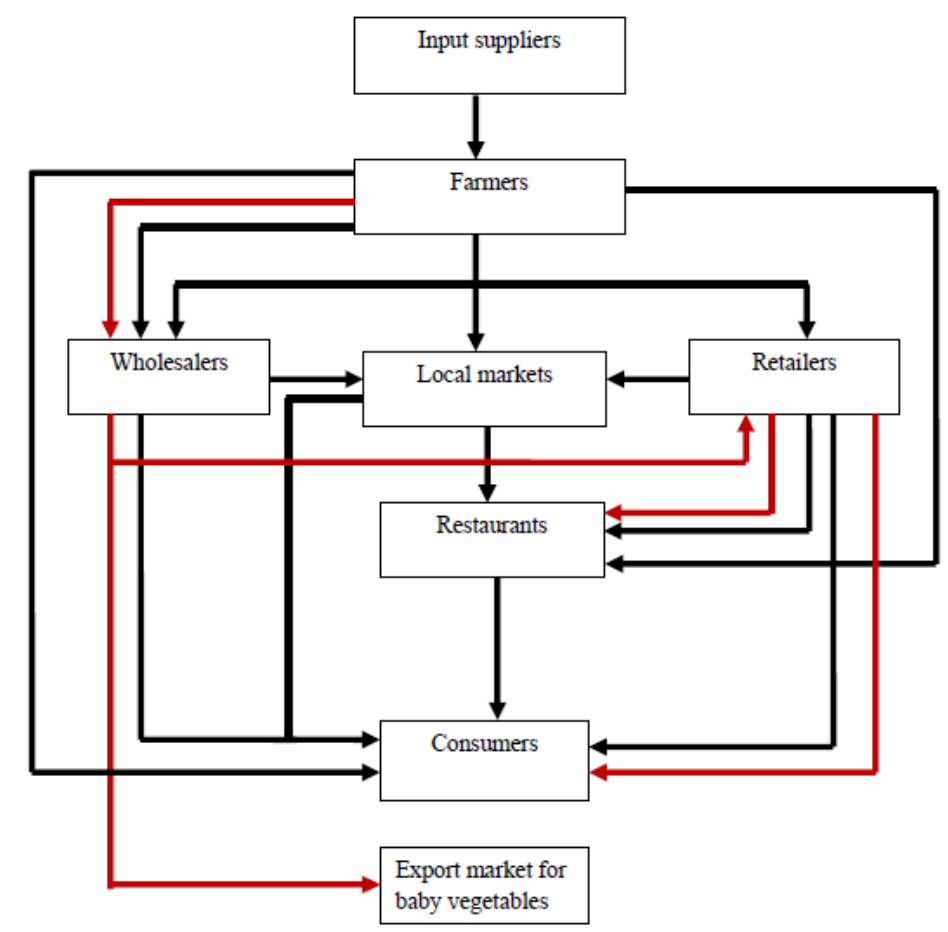

Figure 1. Supply chain for vegetables

Note: Black line denotes the flow of conventional vegetables and the red line denotes the flow of baby vegetables.

\subsection{Marketing Channels}

\subsubsection{Cabbage Marketing Channels}

Table 1 presents the channels through which cabbage is marketed. The results showed that $159155.2 \mathrm{~kg}$ of cabbage was sold through these channels. Results further revealed that $30 \%$ of cabbage was sold direct to consumers, whilst $17.6 \%$ was each sold through channel-2 and 3 respectively. Table 1 indicates that the largest producer's share $(100 \%)$ was obtained through direct sale, where produce move direct from production to the consumer. This was followed by channel 4 (71.78\%), and $6(71.78 \%)$, then channel 7 with $62 \%$. Channel 8 had the least $(2.31 \%)$ of producer's share of the consumer price. 
Table 1. Market channels and marketing margin analysis for cabbage

\begin{tabular}{|c|c|c|c|c|c|c|c|c|c|c|}
\hline Market actors & \multicolumn{10}{|c|}{ Marketing measures Vegetable market channels (Total cabbage flow $=159155.2 \mathrm{~kg}$ ) } \\
\hline \multirow{3}{*}{$\begin{array}{l}\text { Quantity flow per } \\
\text { season }(\mathrm{kg})\end{array}$} & \multicolumn{10}{|c|}{ CHA-1 CHA-2 CHA-3 CHA-4CHA-5CHA-6CHA-7 CHA-8CHA-9 } \\
\hline & & 48318 & 27960 & 27960 & 15624 & 15624 & 15624 & 3852 & 3852 & 341.16 \\
\hline & & $-30.40 \%$ & $-17.60 \%$ & $-17.60 \%$ & $-9.80 \%$ & $-9.80 \%$ & $-9.80 \%$ & $-2.40 \%$ & $-2.40 \%$ & $-0.20 \%$ \\
\hline Producers & Price $/ \mathrm{kg}$ & 1.73 & 2.18 & 2.18 & 3.23 & 3.23 & 3.23 & 2.14 & 2.14 & 2.93 \\
\hline \multirow[t]{2}{*}{ Markets } & Price $/ \mathrm{kg}$ & & & & & & & 3.45 & 3.45 & \\
\hline & Gross margin $/ \mathrm{kg}$ & & & & & & & 1.31 & 1.31 & \\
\hline \multirow[t]{2}{*}{ Wholesalers } & Price/kg & & 5.62 & 5.62 & & 5.62 & 5.62 & & & \\
\hline & Gross margin $/ \mathrm{kg}$ & & 3.44 & 3.44 & & 2.39 & 2.39 & & & \\
\hline \multirow[t]{2}{*}{ Retailers } & Price $/ \mathrm{kg}$ & & & & 4.5 & 4.5 & 4.5 & & & \\
\hline & Gross margin $/ \mathrm{kg}$ & & & & 1.27 & -1.12 & -1.12 & & & \\
\hline \multirow[t]{2}{*}{ Restaurants } & Price/kg & & & 92.7 & & 92.7 & & & 92.7 & 92.7 \\
\hline & Gross margin $/ \mathrm{kg}$ & & & 87.08 & & 88.2 & & & 89.25 & 89.77 \\
\hline \multicolumn{2}{|c|}{ Total Gross Marketing Margin } & 0 & 3.44 & 90.52 & 1.27 & 89.47 & 1.27 & 1.31 & 90.56 & 89.77 \\
\hline \multicolumn{2}{|c|}{ Producer’s share (\%) } & 100 & 38.79 & 2.35 & 71.78 & 3.48 & 71.78 & 62.03 & 2.31 & 3.16 \\
\hline \multicolumn{2}{|c|}{$\begin{array}{c}\text { Rank of channels by producer's } \\
\text { share }\end{array}$} & 1 & 5 & 8 & 2 & 6 & 2 & 4 & 9 & 7 \\
\hline
\end{tabular}

Channel-1 Producer $\rightarrow$ consumer; Channel-2 Producer $\rightarrow$ wholesaler $\rightarrow$ consumer;

Channel-3 Produce $\rightarrow$ wholesaler $\rightarrow$ restaurant $\rightarrow$ consumer; Channel-4 Producer $\rightarrow$ retailer $\rightarrow$ consumer;

Channel-5 Producer $\rightarrow$ wholesaler $\rightarrow$ retailer $\rightarrow$ restaurant $\rightarrow$ consume;

Channel-6 Producer $\rightarrow$ wholesaler $\rightarrow$ retailer $\rightarrow$ consumer; Channel-7 Producer $\rightarrow$ market $\rightarrow$ consumer;

Channel-8 Producer $\rightarrow$ market $\rightarrow$ restaurant $\rightarrow$ consumer; Channel-9 Producer $\rightarrow$ restaurant $\rightarrow$ consumer.

Table 2. Market channels and marketing margin analysis for carrot

\begin{tabular}{|c|c|c|c|c|c|c|c|c|c|c|}
\hline \multirow[t]{2}{*}{ Market actors } & \multicolumn{10}{|c|}{ Marketing measures Vegetable market channels (Total carrot flow $=40048.04 \mathrm{~kg}$ ) } \\
\hline & & \multicolumn{9}{|c|}{ CHA-1 CHA-2 CHA-3 CHA-4 CHA-5 CHA-6 CHA-7CHA-8CHA-9 } \\
\hline \multicolumn{2}{|c|}{$\begin{array}{l}\text { Quantity flow per } \\
\text { season }(\mathrm{kg})\end{array}$} & $\begin{array}{c}12482 \\
(31.2 \%)\end{array}$ & $\begin{array}{c}2424 \\
(6.1 \%)\end{array}$ & $\begin{array}{c}2424 \\
(6.1 \%)\end{array}$ & $\begin{array}{c}6174 \\
(15.4 \%)\end{array}$ & $\begin{array}{c}6174 \\
(15.4 \%)\end{array}$ & $\begin{array}{c}6174 \\
(15.4 \%)\end{array}$ & $\begin{array}{c}1884 \\
(4.7 \%)\end{array}$ & $\begin{array}{c}1884 \\
(4.7 \%)\end{array}$ & $\begin{array}{l}428.04 \\
(1.1 \%)\end{array}$ \\
\hline Producers & Price/kg & 4.11 & 4.62 & 4.62 & 5.93 & 4.62 & 4.62 & 6.17 & 6.17 & 6.78 \\
\hline \multirow[t]{2}{*}{ Markets } & Price $/ \mathrm{kg}$ & & & & & & & 8.50 & 8.50 & \\
\hline & Gross margin $/ \mathrm{kg}$ & & & & & & & 2.33 & 2.33 & \\
\hline \multirow[t]{2}{*}{ Wholesalers } & Price/kg & & 9.99 & 9.99 & & 9.99 & 9.99 & & & \\
\hline & Gross margin $/ \mathrm{kg}$ & & 5.37 & 5.37 & & 5.37 & 5.37 & & & \\
\hline \multirow[t]{2}{*}{ Retailers } & Price $/ \mathrm{kg}$ & & & & 8.77 & 8.77 & 8.77 & & & \\
\hline & Gross margin $/ \mathrm{kg}$ & & & & 2.84 & 0.27 & 0.27 & & & \\
\hline \multirow[t]{2}{*}{ Restaurants } & Price $/ \mathrm{kg}$ & & & 108.00 & & 108.00 & & & 108.00 & 108.00 \\
\hline & Gross margin $/ \mathrm{kg}$ & & & 98.01 & & 99.23 & & & 101.83 & 101.22 \\
\hline \multicolumn{2}{|c|}{ Total Gross Marketing Margin } & 0 & 5.37 & 103.38 & 2.84 & 104.87 & 5.64 & 2.33 & 101.83 & 101.22 \\
\hline \multicolumn{2}{|c|}{ Producer's share (\%) } & 100 & 46.25 & 4.28 & 67.62 & 4.28 & 52.68 & 72.59 & 5.71 & 6.28 \\
\hline \multicolumn{2}{|c|}{ Rank of channels by producer's share } & 1 & 5 & 8 & 3 & 8 & 4 & 2 & 7 & 6 \\
\hline
\end{tabular}

Channel-1 Producer $\rightarrow$ consumer; Channel-2 Producer $\rightarrow$ wholesaler $\rightarrow$ consumer; 
Channel-3 Produce $\rightarrow$ wholesaler $\rightarrow$ restaurant $\rightarrow$ consumer; Channel-4 Producer $\rightarrow$ retailer $\rightarrow$ consumer;

Channel-5 Producer $\rightarrow$ wholesaler $\rightarrow$ retailer $\rightarrow$ restaurant $\rightarrow$ consume;

Channel-6 Producer $\rightarrow$ wholesaler $\rightarrow$ retailer $\rightarrow$ consumer; Channel-7 Producer $\rightarrow$ market $\rightarrow$ consumer;

Channel-8 Producer $\rightarrow$ market $\rightarrow$ restaurant $\rightarrow$ consumer; Channel-9 Producer $\rightarrow$ restaurant $\rightarrow$ consumer.

\subsubsection{Carrot Market Channels}

Nine marketing channels were identified for carrot. Table 2 indicates that $40048.04 \mathrm{~kg}$ of carrots moved through the nine channels, of which $31.2 \%$ was sold by farmers direct to consumers, $15.4 \%$ was each sold through channel 4, 5 and 6 respectively. Selling direct to restaurants had the least (1.1\%) amount of vegetables. This could because restaurants buy the vegetables to make salads, hence they can only absorb a small amount at a time. Channels -1 , channel- 7 and channel-4 had the highest producer's share of the consumer's price. They had $100 \%, 72.59 \%$, and $67.62 \%$ respectively.

\subsubsection{Onion Market Channels}

Similar to cabbage and carrot, 9 marketing channels existed for onion. Table 3 shows that $7574.05 \mathrm{~kg}$ of onion flows through these channels. The amount that passed through the channels was taken as channel efficiency measurement. Channel-2 and 3 each had 28,923 $\mathrm{kg}(38.2 \%)$ of the total onion marketed. This was followed by channel-1 that had $15213 \mathrm{~kg}(20.1 \%)$. Based on the quantity flow, there is more onion going through channel 2 , followed by channel-1. Channel-4, 5, and 6 each had a flow of $1 \%$. Using producer's share the highest share was in channel-1 (100\%), followed by channel-7 (72.59\%), then channel -4 (65.09\%).

Table 3. Market channels and marketing margin analysis for onion

\begin{tabular}{|c|c|c|c|c|c|c|c|c|c|c|}
\hline \multirow[t]{2}{*}{ Market actors } & \multicolumn{10}{|c|}{ Marketing measures Vegetable market channels (Total onion flow $=7574.05 \mathrm{~kg}$ ) } \\
\hline & & CHA-1 & CHA-2 & CHA-3 & CHA-4 & CHA-5 & CHA-6 & CHA-7 & CHA-8 & 3CHA-9 \\
\hline \multirow{2}{*}{$\begin{array}{l}\text { Quantity flow per } \\
\text { season (kg) }\end{array}$} & & 15213 & 28923 & 28923 & 779 & 779 & 779 & 157 & 157 & 44.05 \\
\hline & & \multicolumn{9}{|c|}{$-20.10 \%-38.20 \%-38.20 \%-1.00 \%-1.00 \%-1.00 \%-0.20 \%-0.20 \%-0.10 \%$} \\
\hline Producers & Price/kg & 4.1 & 3 & 3 & 4.12 & 3 & 3 & 6.17 & 6.17 & 4.6 \\
\hline \multirow[t]{2}{*}{ Markets } & Price $/ \mathrm{kg}$ & & & & & & & 8.75 & 8.75 & \\
\hline & Gross margin $/ \mathrm{kg}$ & & & & & & & 2.58 & 2.58 & \\
\hline \multirow[t]{2}{*}{ Wholesalers } & Price/kg & & 9.99 & 9.99 & & 9.99 & 9.99 & & & \\
\hline & Gross margin $/ \mathrm{kg}$ & & 6.99 & 6.99 & & 6.99 & 6.99 & & & \\
\hline \multirow[t]{2}{*}{ Retailers } & Price/kg & & & & 6.33 & 6.33 & 6.33 & & & \\
\hline & Gross margin $/ \mathrm{kg}$ & & & & 2.21 & -3.66 & -3.66 & & & \\
\hline \multirow[t]{2}{*}{ Restaurants } & Price/kg & & & 58.32 & & 58.32 & & & 58.32 & 58.32 \\
\hline & Gross margin $/ \mathrm{kg}$ & & & 48.33 & & 51.99 & & & 49.57 & 53.72 \\
\hline \multicolumn{2}{|c|}{ Total Gross Marketing Margin } & 0 & 6.99 & 55.32 & 2.21 & 55.32 & 3.33 & 2.58 & 52.15 & 53.72 \\
\hline \multicolumn{2}{|c|}{ Producer's share (\%) } & 100 & 30.03 & 5.14 & 65.09 & 5.14 & 10.36 & 72.59 & 10.58 & 7.89 \\
\hline \multicolumn{2}{|c|}{ Rank of channels by producer's share } & 1 & 4 & 8 & 3 & 8 & 6 & 2 & 5 & 7 \\
\hline
\end{tabular}

Channel-1 Producer $\rightarrow$ consumer; Channel-2 Producer $\rightarrow$ wholesaler $\rightarrow$ consumer;

Channel-3 Produce $\rightarrow$ wholesaler $\rightarrow$ restaurant $\rightarrow$ consumer; Channel-4 Producer $\rightarrow$ retailer $\rightarrow$ consumer;

Channel-5 Producer $\rightarrow$ wholesaler $\rightarrow$ retailer $\rightarrow$ restaurant $\rightarrow$ consume;

Channel-6 Producer $\rightarrow$ wholesaler $\rightarrow$ retailer $\rightarrow$ consumer; Channel-7 Producer $\rightarrow$ market $\rightarrow$ consumer;

Channel-8 Producer $\rightarrow$ market $\rightarrow$ restaurant $\rightarrow$ consumer; Channel-9 Producer $\rightarrow$ restaurant $\rightarrow$ consumer. 
Table 4. Market channels and marketing margin analysis for tomato

\begin{tabular}{|c|c|c|c|c|c|c|c|c|c|c|}
\hline Market actors & Marketing measures & Veget & able mark & ket chann & els (Tot & al toma & to flow & $=5141$ & $7.12 \mathrm{~kg}$ & \\
\hline & & CHA-1 & CHA-2 & CHA-3 & CHA-4 & $\overline{\mathrm{CHA}-5}$ & CHA-6 & $\overline{\mathrm{CHA}-7}$ & $\overline{\text { CHA-8 }}$ & CHA-9 \\
\hline Quantity flow per & & 13288 & 12696 & 12696 & 3456 & 3456 & 3456 & 1064 & 1064 & 241.12 \\
\hline season (kg) & & $-25.80 \%$ & $0-24.70 \%$ & $-24.70 \%$ & $-6.70 \%$ & $-6.70 \%$ & $-6.70 \%$ & $-2.10 \%$ & $-2.10 \%$ & $-0.50 \%$ \\
\hline Producers & Price/kg & 4.94 & 6.3 & 6.3 & 6.71 & 6.3 & 6.3 & 5.82 & 5.82 & 8.57 \\
\hline Markets & Price $/ \mathrm{kg}$ & & & & & & & 8.7 & 8.7 & \\
\hline & Gross margin $/ \mathrm{kg}$ & & & & & & & 2.88 & 2.88 & \\
\hline Wholesalers & Price $/ \mathrm{kg}$ & & 8 & 8 & & 8 & 8 & & & \\
\hline & Gross margin $/ \mathrm{kg}$ & & 1.7 & 1.7 & & 1.7 & 1.7 & & & \\
\hline Retailers & Price $/ \mathrm{kg}$ & & & & 10.34 & 10.34 & 10.34 & & & \\
\hline & Gross margin $/ \mathrm{kg}$ & & & & 3.63 & 2.34 & 2.34 & & & \\
\hline Restaurants & Price $/ \mathrm{kg}$ & & & 60.8 & & 60.8 & & & 60.8 & 60.8 \\
\hline & Gross margin $/ \mathrm{kg}$ & & & 52.8 & & 50.46 & & & 52.1 & 52.23 \\
\hline Total Gross Marke & ng Margin & 0 & 1.7 & 54.5 & 3.63 & 54.5 & 4.04 & 2.88 & 54.98 & 52.23 \\
\hline Producer's share ( & & 100 & 78.75 & 10.36 & 64.89 & 10.15 & 10.36 & 66.9 & 9.57 & 14.1 \\
\hline Rank of channels & producer's share & 1 & 2 & 6 & 4 & 8 & 6 & 3 & 9 & 5 \\
\hline
\end{tabular}

Channel-1 Producer $\rightarrow$ consumer; Channel-2 Producer $\rightarrow$ wholesaler $\rightarrow$ consumer;

Channel-3 Produce $\rightarrow$ wholesaler $\rightarrow$ restaurant $\rightarrow$ consumer; Channel-4 Producer $\rightarrow$ retailer $\rightarrow$ consumer;

Channel-5 Producer $\rightarrow$ wholesaler $\rightarrow$ retailer $\rightarrow$ restaurant $\rightarrow$ consume;

Channel-6 Producer $\rightarrow$ wholesaler $\rightarrow$ retailer $\rightarrow$ consumer; Channel-7 Producer $\rightarrow$ market $\rightarrow$ consumer;

Channel-8 Producer $\rightarrow$ market $\rightarrow$ restaurant $\rightarrow$ consumer; Channel-9 Producer $\rightarrow$ restaurant $\rightarrow$ consumer.

Table 5. Market channels and marketing margin analysis for baby corn

\begin{tabular}{|c|c|c|c|c|c|c|c|c|}
\hline \multirow[t]{2}{*}{ Market actors } & \multirow[t]{2}{*}{ Marketing measures } & \multicolumn{7}{|c|}{ Vegetable market channels (Total baby corn flow $=21080.94 \mathrm{~kg}$ ) } \\
\hline & & CHA-1 & $1 \mathrm{CHA}-2$ & CHA-3 & CHA-4 & CHA- & $\overline{5 \mathrm{CHA}-6}$ & $\overline{6 \mathrm{CHA}-7}$ \\
\hline \multirow{2}{*}{\multicolumn{2}{|c|}{$\begin{array}{l}\text { Quantity flow per } \\
\text { season }(\mathrm{kg})\end{array}$}} & 1593 & 6420 & 6420 & 6420 & 96.72 & 96.72 & 34.5 \\
\hline & & -7.6 & $-30.50 \%$ & $0-30.50 \%$ & $0-30.50 \%$ & $6-0.50 \%$ & $0-0.50 \%$ & $0-0.20 \%$ \\
\hline Producers & Price/kg & 19.94 & 5.75 & 5.75 & 5.75 & 27.1 & 27.1 & 11.63 \\
\hline \multirow[t]{2}{*}{ Wholesalers } & Price/kg & & 9.23 & 9.23 & 9.23 & & & \\
\hline & Gross margin $/ \mathrm{kg}$ & & 3.48 & 3.48 & 3.48 & & & \\
\hline \multirow[t]{2}{*}{ Retailers } & Price $/ \mathrm{kg}$ & & & 31.38 & & 31.38 & 31.38 & \\
\hline & Gross margin $/ \mathrm{kg}$ & & & 22.15 & & 4.28 & 4.28 & \\
\hline \multirow[t]{2}{*}{ Restaurants } & Price $/ \mathrm{kg}$ & & & & 292 & & 292 & 292 \\
\hline & Gross margin $/ \mathrm{kg}$ & & & & 282.77 & & 260.62 & 280.37 \\
\hline \multicolumn{2}{|c|}{ Total Gross Marketing Margin } & 0 & 3.48 & 25.63 & 286.25 & 4.28 & 264.9 & 280.37 \\
\hline \multicolumn{2}{|c|}{ Producer's share (\%) } & 100 & 62.3 & 18.32 & 1.97 & 86.36 & 9.28 & 3.98 \\
\hline \multicolumn{2}{|c|}{ Rank of channels by producer's share } & 1 & 3 & 4 & 7 & 2 & 5 & 6 \\
\hline
\end{tabular}

Channel-1 Producer $\rightarrow$ consumer; Channel-2 Producer $\rightarrow$ wholesaler $\rightarrow$ consumer;

Channel-3 Produce $\rightarrow$ wholesaler $\rightarrow$ restaurant $\rightarrow$ consumer; Channel-4 Producer $\rightarrow$ wholesaler $\rightarrow$ consumer;

Channel-5 Producer $\rightarrow$ retailer $\rightarrow$ retailer $\rightarrow$ restaurant $\rightarrow$ consume;

Channel-6 Producer $\rightarrow$ retailer $\rightarrow$ restaurant $\rightarrow$ consumer; Channel-7 Producer $\rightarrow$ restaurant $\rightarrow$ consumer. 
Table 6. Market channels and marketing margin analysis for baby marrow

\begin{tabular}{|c|c|c|c|c|c|c|c|c|}
\hline Market actors & Marketing measures & Vegetable market $\mathrm{c}$ & annels & Total ba & by marro & ow flow & $y=1569$ & $4.52 \mathrm{~kg})$ \\
\hline & & CHA-1 & CHA-2 & CHA-3 & CHA-4 & CHA-5 & $\overline{5 \mathrm{CHA}-6}$ & CHA-7 \\
\hline Quantity flow per & & 5573 & 3120 & 3120 & 3120 & 229.56 & 5229.56 & 302.4 \\
\hline season (kg) & & $35.5 \%$ & $19.90 \%$ & $-19.90 \%$ & $-19.90 \%$ & $0-1.50 \%$ & $0-1.50 \%$ & $-1.90 \%$ \\
\hline Producers' & Price $/ \mathrm{kg}$ & 12.42 & 8.79 & 8.79 & 8.79 & 20.22 & 20.22 & 35.45 \\
\hline Wholesalers & Price $/ \mathrm{kg}$ & & 9.67 & 9.67 & 9.67 & & & \\
\hline & Gross margin $/ \mathrm{kg}$ & & 0.88 & 0.88 & 0.88 & & & \\
\hline Retailers & Price $/ \mathrm{kg}$ & & & 48.14 & & 48.14 & 48.14 & \\
\hline & Gross margin $/ \mathrm{kg}$ & & & 38.47 & & 27.92 & 27.92 & \\
\hline Markets & Price $/ \mathrm{kg}$ & & & & & & & \\
\hline & Gross margin $/ \mathrm{kg}$ & & & & & & & \\
\hline Restaurants & Price/kg & & & & 348.38 & & 348.38 & 348.38 \\
\hline & Gross margin $/ \mathrm{kg}$ & & & & 338.71 & & 300.24 & 312.93 \\
\hline Total Gross Marke & ing Margin & 0 & 0.88 & 39.35 & 339.59 & 27.92 & 328.16 & 312.93 \\
\hline Producer's share (' & & 100 & 90.9 & 18.26 & 2.52 & 42 & 5.8 & 10.18 \\
\hline Rank of channels t & producer's share & 1 & 2 & 4 & 7 & 3 & 6 & 5 \\
\hline
\end{tabular}

Channel-1 Producer $\rightarrow$ consumer; Channel-2 Producer $\rightarrow$ wholesaler $\rightarrow$ consumer;

Channel-3 Produce $\rightarrow$ wholesaler $\rightarrow$ restaurant $\rightarrow$ consumer; Channel-4 Producer $\rightarrow$ wholesaler $\rightarrow$ consumer;

Channel-5 Producer $\rightarrow$ retailer $\rightarrow$ retailer $\rightarrow$ restaurant $\rightarrow$ consume;

Channel-6 Producer $\rightarrow$ retailer $\rightarrow$ restaurant $\rightarrow$ consumer; Channel- 7 Producer $\rightarrow$ restaurant $\rightarrow$ consumer.

\subsection{Tomato Market Channels}

Nine market channels were identified for tomato and the amount of tomato flowing through these channels was $51417.12 \mathrm{~kg}$. Most $(25.8 \%)$ of the tomato was through channel-1, where farmers sell direct to consumers. This is followed by channel-2 (24.7\%). Channel-9 had the least (0.05\%) tomato going through it. The producer's share indicates that channel-1 had the highest (100\%) producer's share, followed by channel-2 (78.8\%) and channel-7 $(66.9 \%)$.

\subsection{Baby Corn Market Channels}

Table 5 presents the flow of baby corn and it shows that $21080.94 \mathrm{~kg}$ of baby corn flows in seven marketing channels. The most of the baby corn flows through channels 2, 3, and 4 . They account for $30.5 \%$ each of the total baby corn. Restaurants received low quantities of baby corn of about $34.56 \mathrm{~kg}(0.2 \%)$. This may be because local consumers are not familiar with baby vegetables. Channel-1, channel- 5 and channel- 2 had the $100 \%$, $86.4 \%$, and $62.3 \%$ producer's share respectively.

\subsection{Baby Marrow Market Channels}

Seven marketing channels were identified for baby marrow as indicated in Table 6 . The results revealed that $15694.52 \mathrm{~kg}$ of baby marrow flow through the seven channels. Most $(35.5 \%)$ of the bay marrow goes through channel-1, whilst channel-2, 3, and 4 account for $19.9 \%$ each. Channel- 6 accounted for only $1.5 \%$ of the baby marrow in the market. According to the producer's share, channel -1 had $100 \%$, whilst channel 2 followed with $90 \%$. The lowest producer's share was found in channel-4.

\section{Conclusions}

Farmers growing baby vegetables relied on wholesalers to purchase their produce. Wholesalers were mainly located in the Manzini region and operated at retail and assembling level. Retailers purchased vegetables from local vegetable farmers, local wholesalers and also from foreign retailers. They then sold them to market vendors, restaurants and consumers. The highest producer's share was obtained through the channel-1, which is selling direct to consumers. Channels that included restaurants had high total gross margins and low producer's share of 
the consumer price and market margins were higher in channels that involved restaurants. Selling direct to consumers is the most channel used for when selling vegetable mainly because they sell at a higher price compared to selling to wholesalers.

\section{Recommendations}

The channel analysis and gross margin results of the supply chain performance revealed different channels that producers use. Vegetable farmers should be assisted in indentifying the best outlet. Hence, farmers should be encouraged to join co-operatives because they can collate farmers' produce and enable them to have bargaining power for input and product prices. This could assist farmers to find markets and access information about the demand, supply and price of vegetables. In turn this would motivate them to increase their production as a result of economies of scale.

\section{References}

Abbott, J. C., \& Markham, J. P. (1981). Agricultural Economics and Marketing in the Tropics. Intermediate Tropical Agricultural Series, Longman, UK.

Abebe, A. (2009). Market chain analysis of honey production: In Atsbi Wemberta District, Eastern Zone of Tigray National Region State. Unpublished MSc. Thesis. Haramaya University, Ethiopia.

Emana, B., \& Gebremedhin, H. (2007). Constraints and Opportunities of Horticultural Production and Marketing in Eastern Ethiopia. Dry lands Coordination Group Report No. 46.

FAO. (1986). Marketing improvement in the developing world. Marketing and Credit Service. Rome, Italy.

FAO/WFP. (2002). Swaziland Special Report. FAO/WFP crop and food supply assessment mission to Swaziland. Mbabane, Swaziland.

Ghorbani, M. (2008). The efficiency of Saffron's Marketing Channel in Iran. World Applied Sciences Journal, 4(4), 523-527. http://www.idosi.org/wasj/wasj4(4)/7.pdf, 10/9/12

Hettige, S. T., \& Senanayake, S. M. P. (1992). Highland Vegetable Production and Marketing Systems. A report prepared for Agriculture Cooperative Development International/USAID.

Kodithuwakku, K. A. S. S. (2000). Analysis of Tomato Supply Chains in the Kandy district. An unpublished report prepared for the University of Peradeniya.

Lambert, D. R., \& Cooper, M. C. (2000). Issues in supply chain management. Industrial Marketing Management, 29(1), 65-83. http://dx.doi.org/10.1016/S0019-8501(99)00113-3

Makhura, M., \& Mokoena, M. (2003). Market Access for Small-Scale Farmers in South Africa. In: L. Nieuwoudt \& J. Groenewald (eds.). The Challenge of Change, Pietermaritzburg, University of Natal Press.

NAMBoard. (2009). Annual Report for National Agricultural Marketing Board, 2009. Manzini, Swaziland.

NAMBoard. (2011). Annual Report for National Agricultural Marketing Board, 2011. Manzini, Swaziland.

Porter, M. E. (1985). Competitive Advantage. The Free Press, New York.

Sekhon, M. K., \& Kaur, M. (2004). Role of small farmers in diversification of Punjab agriculture with vegetables, Indian Journal of Agricultural Marketing, 18(1), 80-88.

Shiferaw, B., Obare, G., \& Muricho, G. (2006). Rural Institutions and Producer Organizations in Imperfect markets: Experiences from Producer Marketing groups in semi-arid Eastern Kenya. IFPRI Working paper 60, International Food Policy Research Institute, Washington DC.

Sithole, D., \& Grenoble, D. (2010). Status of production and marketing of vegetables in Swaziland and the role of National Agricultural Marketing Board. Mbabane, Swaziland.

Stern, L. W., \& El-Ansary, A. I. (1977). Marketing channels. Prentice-Hall Inc. Englewood Cliffs, New Jersey.

Teka, S.G. (2009). Analysis of Fruit and Vegetables Market Chains in Alamata Southern Zone of Tigray: The case of Onion, Tomato, and Papaya, Unpublished MSc. Thesis, Haramaya University, Haramaya, Ethiopia.

Thompson, C. F. (2011). Swaziland Business Year Book. Christina Forsyth Thompson, Mbabane-Swaziland. 